\title{
PENAMBAHAN ALAT PRODUKSI GUNA MENINGKATKAN PRODUKTIVITAS PENGRAJIN KESET
}

\section{ADDING PRODUCTION TOOLS TO INCREASE PRODUCTIVITY OF DOORMAT CRAFTSMEN}

\author{
${ }^{1)}$ Rosita Dwi Ferdiani, ${ }^{2)}$ Tatik Retno Murniasih, ${ }^{3)}$ Sri Wilujeng, ${ }^{4)}$ Vivi Suwanti \\ ${ }^{1,2,4)}$ Program Studi Pendidikan Matematika, ${ }^{3)}$ Program Studi Manajemen Universitas Kanjuruhan \\ Universitas Kanjuruhan Malang \\ email: ${ }^{1)}$ Rositazahra22@gmail.com , ${ }^{2)}$ tretnom@ @nikama.ac.id , ${ }^{3)}$ media_myajeng@yahoo.co.id , \\ 4)vivi_devbatghost@unikama.ac.id
}

\begin{abstract}
ABSTRAK
Pasuruan dikenal sebagai kawasan perindustrian karena banyak industri bertaraf nasional ataupun internasional. Tetapi, dampak negatif dari pembangunan kawasan industri adalah limbah industri. Tidak semua limbah industri tidak bermanfaat. Limbah industri konveksi dapat dimanfaatkan untuk bahan baku keset. Pengrajin keset yang memanfaatkan limbah konveksi adalah kelompok usaha "Sukoda Unggul" dan "Damarjati Maslahat" yang terletak di Desa Karangrejo, Kecamatan Purwosari, Pasuruan. Berdasarkan analisis situasi, permasalahan yang dihadapi kedua mitra adalah: a) Produktivitas rendah, sedangkan permintaan pasar tinggi. b) Kekurangan alat produksi, berupa mesin jahit jahit dan mesin bordir. c) Desain keset masih standart. d) Kontrak pembelian bahan baku (minimal 50 juta). Tujuan dari pengabdian ini adalah: a) Meningkatkan produksi keset kedua mitra melalui penambahan mesin jahit dan mesin bordir, b) Meningkatkan produktivitas, c) Menjalin kerjasama dengan lembaga keuangan yang dapat memberikan pinjaman modal. Metode yang digunakan dalam program ini adalah diskusi, pelatihan, dan pendampingan. Hasil yang diperoleh dari pelaksanaan pengabdian ini adalah : a) Pemberian alat produksi berupa mesin jahit dan mesin bordir. b) Meningkatnya produksi keset dari 15 kodi menjadi 20 kodi per hari, c) Terbentuknya kelompok pengrajin keset untuk bekerjasama dalam pembelian barang baku, d) Menjalin kerjasama dengan BPR Keraton Surapati, Purwosari, Pasuruan.
\end{abstract}

Kata kunci : Keset, Pengrajin, Karangrejo, Pasuruan

\begin{abstract}
Pasuruan is known as an industrial area because there are many industries in that area, both national and international based industries. However, there are some negative impact from the development of this industrial area, such as industrial waste. Not all industrial waste is useless. Industrial waste from convection can be used as the raw material for doormats. Doormat craftsmen who use the waste from convection are the home industrial groups "Sukoda Unggul" and "Damarjati Maslahat", which are located in Desa Karangrejo, Kecamatan Purwosari, Pasuruan. Based on the situational analysis, the problems faced by both partners are: a) Low productivity, high demand. b) Lack of production tools, such as sewing machines and embroidery machines. c) Standard doormat design. d) Buying contract for raw material (50 million minimum). The aims of this community service are: a) To increase doormat production of both partners by adding sewing machines and embroidery machines, b) To increase productivity, c) To cooperate with financial institutions which can provide capital loan. The methods used in this program are discussion, training, and mentoring. The result obtained from this community service are: a) Granting some production tools, such as sewing machines and embroidery machines. $b$ ) Increasing doormat production from 300 pieces to 400 pieces per day, c) Forming doormat craftsmen group to cooperate in buying the raw material, d) Cooperating with BPR Keraton Surapati, Purwosari, Pasuruan.
\end{abstract}

Keywords: Doormat, Craftsmen, Karangrejo, Pasuruan

Submited : 11 Agustus 2017 Revision : 9 Desember $2017 \quad$ Accepted : 5 Maret 2018 


\section{PENDAHULUAN}

Pasuruan sebagai salah satu kabupaten di Jawa Timur mempunyai posisi strategis. Pasuruan menjadi jalur regional perekonomian Surabaya-Malang dan Surabaya-Banyuwangi. Pasuruan dikenal sebagai kawasan perindustrian karena banyak industri bertaraf nasional ataupun internasional, contoh perusahaan Panasonic, Nestle, Mayora, Sampoerna, Aqua dan perusahaan lainnya.

Dampak positif pembangunan kawasan industri adalah tersedianya lapangan pekerjaan baik langsung maupun tidak langsung sehingga dapat meningkatkan pendapatan dan meningkatkan daya saing produk atau jasa. Sedangkan dampak negatif dari pembangunan kawasan industri adalah limbah industri. Masyarakat kawasan industri inilah yang merasakan dampak buruk dari limbah. Limbah industri adalah hasil sampingan dari proses produksi industri, dapat berbentuk benda padat, cair maupun gas yang dapat menimbulkan pencemaran (Ginting, 2007). Tetapi, tidak semua limbah industri tidak bermanfaat. Apabila dapat dikelola dengan baik, limbah ini dapat dimanfaatkan, bahkan dapat dijadikan sebagai usaha untuk meningkatkan perekonomian masyarakat di sekitar kawasan industri tersebut. Berdasarkan nilai ekonominya, limbah dibedakan menjadi limbah yang mempunyai nilai ekonomis dan limbah yang tidak memiliki nilai ekonomis. Limbah yang memiliki nilai ekonomis yaitu limbah dimana dengan melalui suatu proses lanjut akan memberikan suatu nilai tambah. Limbah non ekonomis adalah suatu limbah yang walaupun telah dilakukan proses lanjut dengan cara apapun tidak akan memberikan nilai tambah kecuali sekedar untuk mempermudah sistem pembuangan (Kristanto, 2002). Salah satu jenis limbah yang dapat dimanfaatkan dan bernilai ekonomi adalah limbah industri konveksi. Limbah ini ternyata dapat dimanfaatkan untuk pembuatan berbagai kerajinan seperti boneka, keset dan kerajinan lainnya yang mempunyai daya jual tinggi.

Salah satu kelompok usaha dalam memanfaatkan limbah pabrik industri adalah kelompok pengrajin keset di desa Karangrejo, Kecamatan Purwosari, Kabupaten Pasuruan. Lebih dari $50 \%$, masyarakat di desa Karangrejo bermata pencaharian sebagai pengrajin keset yang terbuat dari limbah industri konveksi. Mereka memanfaatkan sisa-sisa limbah berupa kain perca atau kain handuk untuk dimanfaatkan sebagai bahan baku keset. Usaha yang masih berskala rumahan ini turut mendorong aktifitas perekonomian di daerah tersebut sehingga roda perekonomian dapat berputar. Produk keset selama ini dibutuhkan dalam skala rumahan maupun perkantoran. Namun sayangnya, usaha produk keset belum dikelola secara professional. Modal awal yang kecil, menyebabkan produktifitas menjadi rendah. Kurangnya persediaan alat produksi juga turut mempengaruhi produksi sehingga tidak bisa memenuhi permintaan pasar. Padahal tenaga kerja melimpah, sehingga mereka banyak yang menganggur atau tidak bekerja. Masalahmasalah tersebut yang menyebabkan usaha pengrajin keset ini menjadi sulit berkembang.

Dari beberapa pengrajin keset di Desa Karangrejo terdapat usaha "Sukoda Unggul" yang berdiri sejak tahun 2011 dan beralamatkan di Jl. Kauman 3 No. 24, RT. 02, RW. 04, Desa Karangrejo, Kecamatan Purwosari. Usaha ini didirikan oleh ibu Nadhomah Alfiyah (42 tahun). Usaha ini bermodal awal 30 juta, dengan keuntungan 5 - 6 juta perbulan. Pada saat ini sudah mempunyai 5 karyawan dan memiliki 4 mesin jahit. Tetapi keuntungan tersebut sebagaian digunakan untuk pemeliharaan mesin jahit.

Selain Sukoda Unggul, terdapat pengrajin keset lainnya yaitu "Damarjati 
Maslahat" yang berdiri sejak tahun 2005 dan berlokasi di Jl. Raya Karangrejo RT. 02, RW. 05, Desa Karangrejo. Usaha ini didirikan oleh ibu Mufida Maslakhah (36 tahun). Dengan bermodal 20 juta, usaha ini

dapat meraup untung sebesar 2,5 - 3 juta perbulan. Pada saat ini sudah mempunyai pekerja sebanyak 3 orang dan memiliki 1 mesin jahit dan 1 mesin tenun. Kedua kelompok usaha ini menghasilkan berbagai macam jenis keset dengan bahan baku yang sama yaitu limbah industri konveksi yang berupa kain perca dan handuk. Dari hasil wawancara dengan pemilik usaha pada tanggal 15 Februari 2016, jenis keset pidang dan handuk busa yang paling diminati oleh konsumen. Berikut ini adalah daftar penjualan dan keuntungan dari kedua kelompok usaha.

Tabel 1. Daftar Penjualan Usaha Sukoda Unggul

\begin{tabular}{|c|c|c|c|c|c|c|c|}
\hline \multirow[b]{2}{*}{ Daftar Produk } & \multicolumn{3}{|c|}{ Daftar Penjualan/Kodi } & \multirow{2}{*}{$\begin{array}{c}\text { Keuntungan } \\
\text { perkodi }\end{array}$} & \multicolumn{3}{|c|}{ Keuntungan Pertahun (Juta) } \\
\hline & 2013 & 2014 & 2015 & & 2013 & 2014 & 2015 \\
\hline Keset Pidangan & 435 & 500 & 475 & 15000 & 6,25 & 7,5 & 7,125 \\
\hline Keset Bulu Benang & 200 & 275 & 280 & 45000 & 9 & 12,375 & 12,6 \\
\hline Keset Bulu Kaos & 250 & 315 & 300 & 80000 & 19,2 & 25,2 & 24 \\
\hline Keset Handuk Busa & 420 & 500 & 525 & 55000 & 23,1 & 27,5 & 28,875 \\
\hline
\end{tabular}

Sumber: Data diolah berdasarkan dari hasil wawancara dengan pemilik usaha

Tabel 2. Daftar Penjualan Usaha Damarjati Maslahat

\begin{tabular}{lccccccrr}
\hline \multirow{2}{*}{ Daftar Produk } & \multicolumn{4}{c}{ Daftar Penjualan/Kodi } & \multicolumn{3}{c}{ Keuntungan } & \multicolumn{3}{c}{ Keuntungan Pertahun (Juta) } \\
& 2013 & 2014 & 2015 & perkodi & 2013 & 2014 & \multicolumn{2}{c}{2015} \\
\hline Keset Pidangan & 415 & 435 & 500 & 15000 & 6,225 & 6,525 & 7,875 \\
Keset Tenun & 325 & 350 & 400 & 17000 & 5,525 & 5,950 & 8,5 \\
Keset Handuk Busa & 510 & 500 & 525 & 55000 & 28,05 & 27,5 & 22 \\
Sumber: Data diolah & berdasarkan & dari & hasil & wawancara & dengan & pemilik & usaha
\end{tabular}

\section{METODE}

Metode yang digunakan dalam pengabdian kepada mitra "Sukoda Unggul" dan Mitra "Damarjati Maslahat" yaitu diskusi, pelatihan, serta pendampingan. Mitra "Sukoda Unggul" yang berdiri sejak tahun 2011 dan beralamatkan di Jl. Kauman 3 No. 24, RT. 02, RW. 04, Desa Karangrejo, Kecamatan Purwosari. Usaha ini didirikan oleh ibu Nadhomah Alfiyah (42 tahun). Mitra Damarjati Maslahat" yang berdiri sejak tahun 2005 dan berlokasi di Jl. Raya Karangrejo RT. 02, RW. 05, Desa Karangrejo. Usaha ini didirikan oleh ibu Mufida Maslakhah (36 tahun).

Diskusi dengan mitra mempunyai tujuan untuk mencari penyelesaian dari permasalahan dan menggali potensi usaha mitra serta melihat peluang pasar. Pelatihan melibatkan ahli mesin dan ahli kewirausahaan. Kehadiran dan partisipasi mitra dalam pelaksanaan pelatihan turut mendukung keberhasilan kegiatan ini. 
Keterlibatan mitra dalam kegiatan ini adalah menyediakan tempat dan fasilitas dalam pelaksanaan kegiatan. Pendampingan pengrajin keset (mitra) dimulai dari: 1) Penambahan alat produksi berupa mesin jahit yang sudah dimodifikasi dengan mesin bordir beserta cara pemakaian dan perawatan mesin, 2) Pendampingan untuk mendapatkan bahan baku dengan pembelian secara bersamasama antar mitra, 3) Pendampingan untuk menjalin kerjasama dengan koperasi atau lembaga keuangan yang dapat memberikan pinjaman modal untuk pengrajin keset, dan 4) Pendampingan pada saat pelatihan.

\section{HASIL DAN PEMBAHASAN}

Hasil dari kegiatan pengabdian ini adalah:

1. Pengadaan alat produksi baru, cara pemeliharaan beserta penggunaan.

Keputusan mengenai investasi mesin merupakan keputusan yang sangat menentukan keberhasilan perusahaan karena keputusan investasi tersebut, menyerap sebagian modal yang ditanamkan dan juga menyangkut dana yang besar serta berdampak dalam jangka yang lama. Dalam setiap investasi memerlukan suatu analisis dan perhitungan yang matang (Kurniawati dalam Prihastono dan Hayati, 2015).

Pada kegiatan ini telah berhasil mengadakan 1 mesin jahit untuk kapasitas industri dan 1 mesin bordir kapasitas industri. Masing - masing mitra mendapat seperangkat mesin jahit dan seperangkat mesin bordir. Dengan adanya penambahan alat produksi diharapkan dapat meningkatkan produksi perharinya. Karena dengan menambah 1 mesin jahit, mitra dapat menjahit 10 kodi perharinya.

Pengabdi mendatangkan ahli mesin jahit untuk memberikan pelatihan tentang pemeliharaan dan cara penggunaan mesin jahit dan mesin bordir. Karena mesin jenis industri ini, merupakan hal yang baru.
Selama ini, kedua mitra memakai mesin biasa. pada pelatihan ini, kedua mitra diberi kesempatan untuk mencoba mengoperasikan kedua mesin tersebut.

Dengan adanya penambahan mesin jahit dan mesin bordir ini memberikan keuntungan yaitu:

a. Dengan menambah 1 mesin jahit, 1 mitra rata - rata dapat menjahit keset sebanyak 5 kodi perharinya (8 jam perhari).

b. Dengan bertambahnya alat produksi berupa mesin jahit dapat meningkatkan jumlah produksi keset sehingga keuntungan meningkat. Keuntungan perkeset 20\% dari harga jual, sehingga mendapat keuntungan $20 \% \quad \mathrm{x} \quad \mathrm{Rp}$ $8000,00 \times 100$ keset $=\operatorname{Rp} 160.000,00$ (perhari). Maka didapat keuntungan selama satu bulan yaitu Rp 160.000,00 x 30 hari $=\operatorname{Rp} 4.800 .000,00$

c. Dengan adanya mesin bordir, mitra dapat mengembangkan desain keset berkarakter dan nama yang diinginkan konsumen. Berdasarkan survey, desain keset berkarakter dan bertulis, banyak diminati oleh konsumen

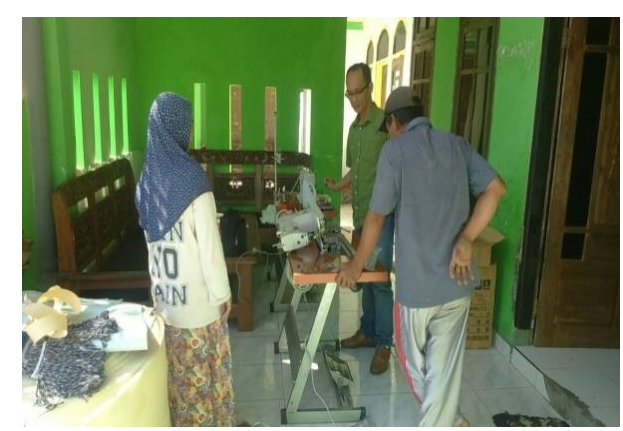

Gambar 1. Pengadaan alat produksi

2. Pelatihan dan pendampingan pengembangan produk keset. Pengembangan sangat diperlukan untuk memperbaharui yang telah ada dengan tujuan yaitu lebih bervariasi dan memberi gambaran baru sesuai dengan perkembangan jaman. (Novitasari \& Fera, 2016) Pengembangan produk yang diberikan ke mitra mencakup: 
a. Keset Anak berkarakter Kartun dan bertulis nama.

b. Keset tenun Rainbow.

c. Keset handuk busa Jumbo

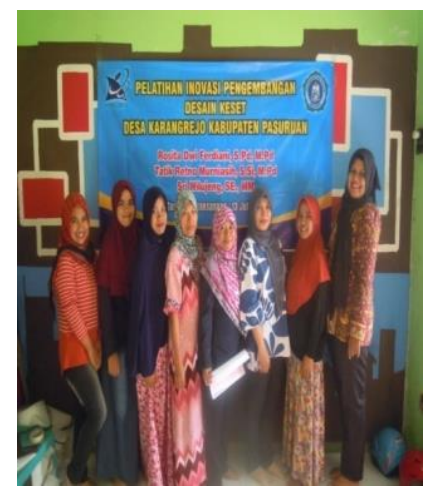

Gambar 2.Pelatihan pengembangan desain

3. Pada kegiatan pelatihan kewirausahaan, pengabdi memberikan materi tentang bagaimana mengembangkan usaha dan memberikan solusi terhadap permasalahan berkenaan dengan modal usaha. Hal ini dikarenakan Pengelolaan manajemen usaha yang lemah banyak menyebabkan usaha kecil macet, dan ketika beranjak usaha tersebut besar akhirnya mengalami kegagalan. (Ambarwati, Nurjanah \& Fitriasari, 2016). Berikut adalah gambar pelatihan kewirausahan.

\section{SIMPULAN}

Kesimpulan yang diperoleh dari kegiatan pengabdian di Desa Karangrejo, Kabupaten Pasuruan adalah sebagai berikut:

1. Pengrajin keset Desa Karangrejo, Kabupaten Pasuruan menerima inovasi peningkatan kualitas dan kuantitas produksi keset.

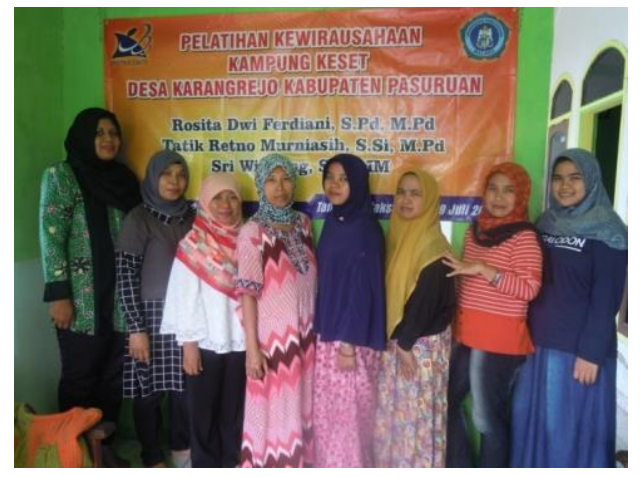

Gambar 3. Pelatihan Kewirausahaan

Hasil yang didapatkan dari pelatihan kewirausahan adalah yaitu:

a. Membentuk kelompok pengrajin keset yang beranggota 3 pengrajin keset untuk bekerjasama dalam pembelian barang baku. Berikut ini adalah gambar pada saat pembentukan kelompok mitra.

b. Menjalin kerjasama dengan BPR Keraton Surapati, Purwasari, Pasuruan.

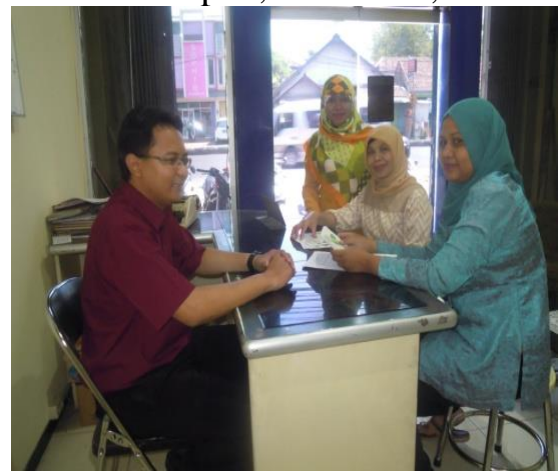

Gambar 4 Menjalin Kerjasama dengan BPR Keraton Surapati

2. Pengrajin keset Desa Karangrejo, Kabupaten Pasuruan menerima inovasi berupa pengembangan desain dan kewirausahaan untuk meningkatkan produktivitas keset sehingga dapat meningkatkan omzet pendapatan 


\section{DAFTAR PUSTAKA}

Ambarwati, T., Nurjannah, D., Fitriasari, F, (2016). IbM Usaha Kreatif Keluarga Miskin (GaKin). Kaji Tindak: Jurnal Pemberdayaan Masyarakat, 3, (1 ), p 39-46

Ginting, P, ( 2007). Sistem Pengelolaan Lingkungan dan Limbah Industri. Cetakan pertama. Bandung: Yrama Widya
Kristianto, P. (2002). Ekologi Industri. Yogyakarta : Penerbit ANDI

Novitasari, I \& Fera, F.,.(2016)

Pengembangan Desain Motif Di

Usaha Batik "Manggur" Probolinggo.

Jurnal Pendidikan Seni Rupa, 04, (02), p 309-316.

Prihastono, E \& Hayati, E. N. (2015). Analisis Kelayakan Investasi Mesin Untuk Meningkatkan Kapasitas Produksi (Studi Kasus di CV Djarum Mulia Embroidery Semarang). Dinamika Teknik, IX, (2 ) , p 47-60. 